\title{
Pass the gas masks, please
}

\section{Munich}

New revelations that German companies have helped virtually every area of Iraqi military development, including its chemical weapons programme, are continuing to rock the government of Chancellor Helmut Kohl. Rather than shipping weapons themselves, it now appears that German companies concentrated on exporting seemingly harmless goods or machinery that could easily be used to make weapons. Among the allegations are that German companies built nerve and mustard gas factories, helped Iraq to enhance its nuclear and biological weapons programmes, built factories for advanced conventional weapons and helped in the attempt to construct the infamous 150-metre-long giant cannon.

In the latest development, a manager and an engineer from two West German companies confessed last week that they had known that they were helping Iraq to build factories that can be used to produce poison gas. Previously they had contended that the factories were to be used for pesticide production (see Nature 332, 573; 1988).

The West German government acknowledged the huge range of shipments in a secret briefing given by Economics Minister Helmut Haussmann to the Economics Committee of the Bundestag in August. According to one committee member, Haussmann admitted that the range of exports was broader than previously suspected and that West German laws would not necessarily be able to prevent future exports, especially of so-called 'dual-use' technology.

Oskar Lafontaine (Social Democrat), who is challenging Kohl (Christian Democrat) for the post of chancellor in the December elections, declared in a speech before the first meeting of an allGerman parliament on 3 October that "it is our responsibility to change the German weapons export policy. We in a new, larger Germany cannot go on [selling] first the gas to Iraq, then the gas masks to Saudi Arabia . ..."West Germany came under severe criticism from the United States last year for its export to Libya of a poison gas plant. The export embarrassed Bonn and caused it to strengthen the laws regulating export of weapons technology, as well as to pursue violators more aggressively. German law is now stricter than that of other European countries and prosecutors are investigating more than 170 companies in 37 separate proceedings, according to the news magazine Der Spiegel.

But it took pressure from the opposition Social Democrats to give the new laws any bite. As passed by the ChristianDemocrat-controlled Bundestag, the

amended laws would not have increased above one year the minimum criminal penalty for violations. The Bundesrat (upper house), which is now controlled by the Social Democrats, forced minimum penalties of two years and more.

The difference is significant, according to Michael Brzoska, an expert on arms control at the University of Hamburg. Traditionally, he says, defendants given one-year sentences are released on probation by German courts. Public prosecutors normally do not expend the tremendous effort necessary to make a case against exporters unless they expect the defendant, if found guilty, to go to prison.

Brzoska, who has written several books on arms exports, says that Bonn deserves FOREIGN RESEARCHERS

\section{Asking for trouble}

\section{Paris}

A SMALL spin-off from the Persian Gulf crisis is causing trouble in the French national research organization, CNRS. First, a government directive was issued asking for the names of all visiting scientists from Iraq. Then Claude Paoletti, director of the life sciences section of CNRS, sent a letter to heads of the 300 CNRS life sciences laboratories asking for the names not just of Iraqis, but also of researchers from Kuwait, Iran, Turkey, Morocco, Algeria, Tunisia, Egypt, Libya, Syria, Jordan, Lebanon and Pakistan. The affair has now caught the eye of the Parisbased League for Human Rights, and Paoletti's action, apparently taken on his own initiative, has brought more opprobrium to an already controversial character (see Nature 339, 326; 1989).

According to Rose Katz, secretary general of SNCS-FEN, the major trade union representing researchers, two Iraqi scientists have already been asked to stay at home. One, a doctoral student in physics, was working on sensitive aerothermal techniques at Meudon, near Paris. The other is a researcher at the national agricultural research institute.

What has particularly irked the union and civil rights bodies is Paoletti's apparently personal decision to extend the scope of the government's request. SNCSFEN was quick to denounce his request as "discriminatory" and to ask its members to ignore the letter.

Meanwhile, the League for Human Rights has opened a dossier on the affair and has requested the national commission on the freedom of information (CNIL) to investigate the legality of CNRS's action in obtaining and filing the information requested. At the end of its bad reputation even though other countries, including France and the Soviet Union, exported more weapons to Iraq. Given the size of its economy, he says, "[West] Germany has been proportionally no worse than other countries", but it has made itself conspicuous by ignoring the problem of illegal or dual-use exports. The export authorities did nothing, he says, when clues poured in concerning "hundreds of cases".

Even after the changes in the law, Brzoska says that Germany could be doing a lot more to stop dubious exports. Industry is often given the benefit of the doubt, he says, because "the export laws are written so that business should be disturbed as little as possible." Instead, Brzoska says, the laws should be rewritten so that everything is checked that might be useful for weapons production.

Steven Dickman
September, the director-general of CNRS, François Kourilsky, issued a statement denying accusations of racism, but leaving Paoletti to fend for himself. "Our concern was only to contact Iraqi researchers", says Kourilsky, who added that the request of the life sciences section to update its list of foreign students was "badly conceived in the current climate of the Gulf crisis". But he said there was no discriminatory intent on Paoletti's part.

Paoletti would not comment last week. But at CNRS headquarters in Paris, JeanFrançois Huchet, reponsible for external relations, confirmed that Paoletti's request for details of visitors from other Muslim countries was routine practice, albeit ill-timed. "The files we keep on researchers have all been authorized by the CNIL", said Huchet. "Dr Paoletti anticipated a little, but we have to keep these files up to date." Huchet said that under special circumstances, such as the Gulf crisis, or the massacre of Chinese students in Beijing, the administration may ask for a head-count of students potentially implicated. "I think this is good management", says Huchet. "If we did not know where visiting students are or what there status is, we would be accused of sloppiness".

Some directors of life sciences laboratories have followed union advice and ignored Paoletti's letter. "If he wants to check up on foreign students he should call in the police", said one laboratory director - a reaction that Huchet called "professional misconduct".

Meanwhile, the president of the League of Human Rights is still not satisfied with Kourilsky's explanation and is waiting for the CNIL to give its opinion on the legality of CNRS files.

Peter Coles 